UDC 631.582: 631.8

https://doi.org/10.33619/2414-2948/44/16

AGRIS: F04

\title{
SOME ASPECTS OF RECYCLING AND STORAGE OF SECONDARY RESOURCES OF GRAPE
}

CGvinianidze T., ORCID: 0000-0002-1986-2247, Dr. habil., Akaki Tsereteli State University, Kutaisi, Georgia, temuri1951@mail.ru

CKamkamidze N., Ph.D., Akaki Tsereteli State University, Kutaisi, Georgia,natia.kam@yandex.com

CTsutskiridze N., Dr., Akaki Tsereteli State University, Kutaisi, Georgia,nino.tsutskiridze@atsu.edu.ge

\section{НЕКОТОРЫЕ АСПЕКТЫ ПЕРЕРАБОТКИ И ХРАНЕНИЯ ВТОРИЧНЫХ РЕСУРСОВ ВИНОГРАДА}

(С Гвинианидзе Т. Н., ORCID: 0000-0002-1986-2247, д-р техн. наук, государственный университет им. Акакия Церетели, г. Кутаиси, Грузия, tетиri1951@таil.ru

(СКамкамидзе Н. Р., канд. техн. наук, государственный университет им. Акакия Церетели, 2. Кутаиси, Грузия, natia.kam@yandex.com

СЦуцкиридзе Н. Р., канд. техн. наук, государственный университет им. Акакия Церетели, г. Кутаиси, Грузия, nino.tsutskiridze@atsu.edu.ge

Abstract. According to the National Wine Agency, grape harvesting in Georgia exceeded 231 thousand tons in 2018. Vineyards are not only growing in Kakheti and Racha-Lechkhumi regions, but in almost every area of viticulture. In the process of primary grape harvesting and wine production, up to $25 \%$ waste is generated by solid parts of the grape bunches (bunch, skin, grape seed) and emptying, which are the best raw materials for making the curing-preventive powder, extracts, syrups, concentrates, pills, granules, alcohol, wine acid, grape seed oil, grape seed flour, nutriment paints, pectin, food fiber, tannin, granulated feed-stuff, the animal nutrition silage, fertilizers, etc. for the production of many other precious products. Therefore, it is more relevant to study the optimal technologies of recycling of secondary resources of thousands of tons of grape.

Аннотация. По данным Национального агентства вина, сбор винограда в Грузии в 2018 г. превысил 231 тыс т. Виноградники растут не только в Кахетии и Рача-Лечхуми, но и практически во всех областях виноградарства. В процессе первичного сбора винограда и производства вина до 25\% отходов образуется из твердых частей виноградных гроздей (гребней, кожуры, семян). Из жидкого осадка получают лучшее сырье для лечебнопрофилактического порошка, экстрактов, сиропов, концентратов, пилюль, гранул, спиртасырца, винной кислоты, масла из косточек, муки из косточек, пищевых красителей, пектина, пищевой клетчатки, танина, а также гранулированный комбикорм - корм для животных, добавляемый в силос, удобрения и т. п. Таким образом, отходы используются для производства многих ценных продуктов и поэтому более актуальным является изучение оптимальных технологии переработки вторичных ресурсов тысяч тонн винограда.

Keywords: grape, bunch, skin, grape seeds, emptying, extract, vine, waste.

Ключевые слова: виноград, гребни, кожура, косточки, жидкий осадок, экстракт, лоза, отходы. 


\section{Introduction}

In 2018, grape harvest in Georgia exceeded 231 thousand tons by the data of the National Wine Agency and the number of wastes produced in the wine industry exceeded 57,000 tons (18$25 \%$ ) of the grape bunches and only a very small part of the production of alcohol and a large part of this waste will be used is disposed, while the waste is far more valuable than the wine itself.

Diagram (Figure 1) shows that grape harvesting in Georgia has increased by almost 4,5 times in 2012 compared to 2012. This process continues to increase demand for Georgian wines at international markets (http://georgianwine.gov.ge).

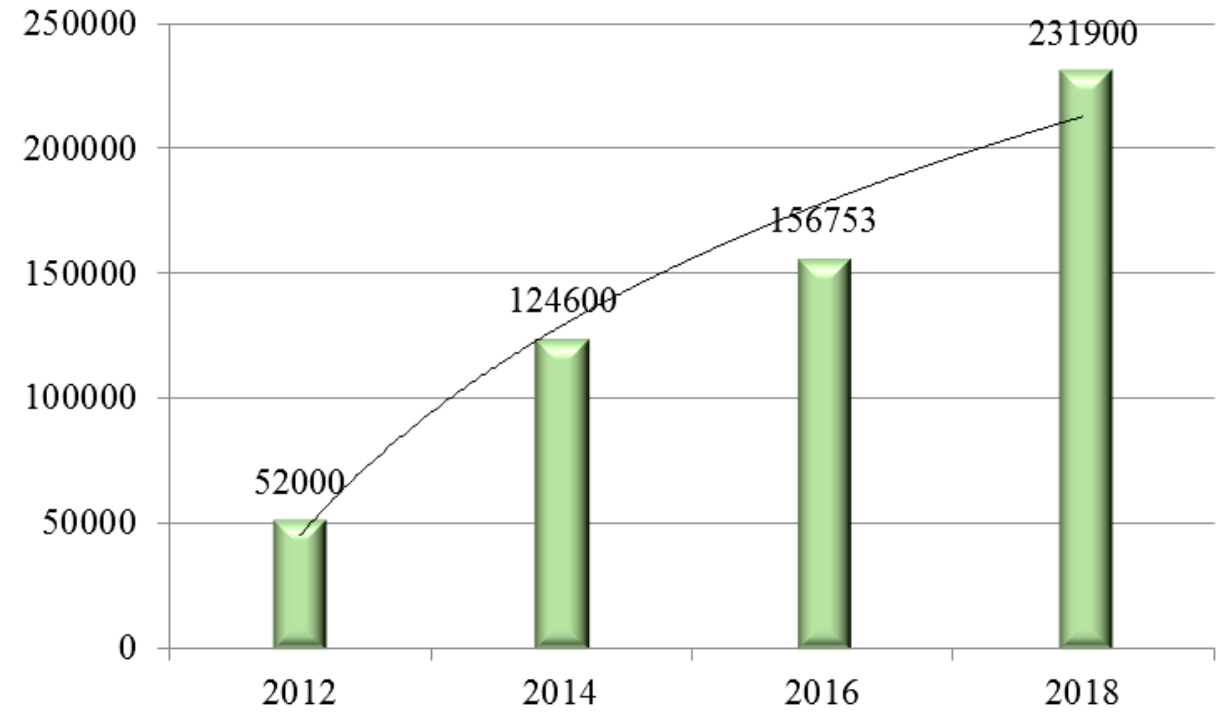

Figure 1. Grape harvest increasing dynamics in Georgia from 2012 to 2018, tons

The secondary resources obtained during the primary processing of the grape raw material and the winemaking processes are not less valuable products of their chemical composition than the solid parts of the grape bunches (bunch, skin, grape seed) and wine-making emptying, rather than wine and other grape products (https://clustermdua.org) [1-4].

In Figure 2, it is shown in the grape clusters, the quantity of juice and millet with the solid parts of the clusters. The bunch in the cluster is about 3,6-4,5\%, and the remaining $96,5-96,4 \%$ are the seeds. The berries are made of skin, juice and seed. The juice and pulp are used for the production of alcoholic and non-alcoholic beverages, and the solid parts are very rich in biologically active compounds and can be obtained with very large range of products.

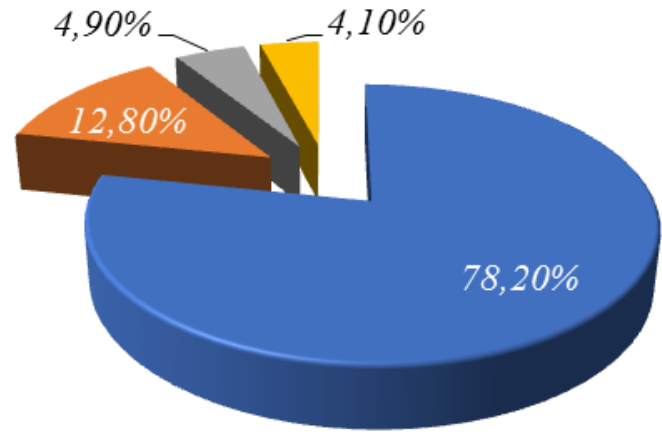

国uice and pulp

回 grape skin

回seed

abunch

Figure 2. The parts of liquid and solid sections of the grape in cluster

It is true, that juice and pulp take $80 \%$ of cluster, but they contain only $10 \%$ of bioflavonoids, and the remaining $90 \%$ are in the solid parts of the cluster. 
Polyphenol extracts and concentrates of strong antioxidant activity are successfully used in developing countries to prevent pathologies such as eye, cardiovascular, oncological and other pathologies (https://www.comodity.ru/vinebrandy/193.shtml) [5, 6].

Due to the high content of phenolic compounds of the interesting aspects of the skin and seeds of grapes micro-dispersion powders, extracts them from these extracts and concentrates of biologically active compounds vacuum condensed enriched composition or therapeutic-preventive use food concentrates and the remaining resources $\mathrm{N}$ supply of animal feed of processing technology.

\section{Materials and Methods}

The research objective was the secondary resources produced by the primary processing of cultivated grape in the viticulture and winemaking zones of Georgia in individual regions.

The objective of research was to search the methods of complex processing of these resources, which would be used to maximize the biological active compounds of solid parts of the grape bunches (bunch, skin, grape seed).

High pressure chromatographic and detective methods were used for researchMethods of high pressure (HPLC) and ultra high pressure deterioration chromatography (UPLC), as well as gasbased gas chromatography (GS) and near infrared spectrophotometers (NIRS) [7].

We used to determine the antioxidant activity of the compounds DPPH (2,2-Diphenyl-1-pic rylhydrazil) and ABTS (2,2-Azino-bis(3-ethylbenz-thiazoline-6-sulfonic acid), which is a quick, easy and accurate test method.

Super Fluid Extractor SFE - 100-2-C10 of Water Corporation was used for supplemental hybrid superfluid supplementation. It was obtained from the extract of powder and phenolic compounds from the cheese and oil from the spray.

We used lipophilic or sublimative and vacuum-rotational treatment methods for the use of extracts and samples.

\section{Results and Discussion}

We have studied the weave of some colorful grape raw materials in the viticulture and winemaking zone of Imereti (Table 1). The study found that there is a significant difference between the weevil indicators of the solid parts of grape bunches of individual varieties. There is therefore a difference between the number of waste generated in their primary processing process.

Table 1

THE CHARACTERISTICS OF CULTIVATED COLORED GRAPE VARIETIES IN IMERETI VITICULTURE AND WINEMAKING ZONE

\begin{tabular}{lcccccc}
\hline \multirow{2}{*}{ Vine breed } & $\begin{array}{c}\text { Average weight } \\
\text { of cluster, } \text { g. }\end{array}$ & lo0 berry & \multicolumn{4}{c}{ cluster mechanical composition, \% } \\
\cline { 5 - 7 } & 205 & 207 & 3,6 & 14,8 & 5,2 & 76,4 \\
\hline Aladasturi & 122 & 123 & 2,7 & 15,1 & 4,1 & 78,1 \\
Otskhanuri sapere & 183 & 187 & 2,3 & 12,4 & 2,2 & 83,1 \\
Dzelshavi & 124 & 136 & 3,1 & 15,0 & 3,3 & 78,6 \\
Chkhaveri & 99 & 112 & 3,2 & 15,5 & 4.4 & 76,9 \\
Zeimberi & 103 & 117 & 4,8 & 16,1 & 3,2 & 75,9 \\
Ojaleshi-clon & 96 & 111 & 4,4 & 15,8 & 4,7 & 75,1 \\
Jvarisa-clon & & & & &
\end{tabular}

The analysis of biochemical indices Zeimberi (ie Zeibel 5455) or environmentally friendly chemicals without using colored grapes cultivated individual parts of the raw materials (Table 2) 
showed us how valuable grape-processing of secondary resources for treatment and prevention of food and feed concentrates $t$ for household items.

Table 2

BIOCHEMICAL INDICATORS OF INDIVIDUAL PARTS OF ZEIBEL GRAPE

\begin{tabular}{lcccc}
\hline \multicolumn{1}{c}{ Indicators } & berry & pulp & seed & skin \\
\hline Dry substance, \% & $24,44 \pm 0,17$ & $12,0 \pm 0,18$ & $64,2 \pm 0,98$ & $17,0 \pm 0,94$ \\
Tytr. acidity,\% & $9,5 \pm 0,12$ & $9,9 \pm 0,12$ & - & $14,35 \pm 0,16$ \\
Flavonoids,\% & $0,19 \pm 0,04$ & $0,69 \pm 0,07$ & $2,93 \pm 0,09$ & $1,5 \pm 0,07$ \\
Anthocyanins, \% & $0,21 \pm 0,03$ & - & $0,83 \pm 0,05$ & $1,1 \pm 0,08$ \\
Phenol. Compound, mg/cm 3 & $1,71 \pm 0,12$ & $0,11 \pm 0,06$ & $2,96 \pm 0,05$ & $1,85 \pm 0,09$ \\
Pectin, \% & $0,27 \pm 0,03$ & $0,22 \pm 0,04$ & $0,51 \pm 0,09$ & $0,30 \pm 0,15$ \\
\hline
\end{tabular}

The colorful grapes of the Zeibel breed are the only varieties in the clones and hybrids in which the antioxidant diglocide compounds in the skin are in the norms defined by the EU Directives (EU №1493/1999, Article 19 and EU №883/2001, Article 21) and therefore the alcoholic fermentation of grape must Let's work together with parts.

Table 3 presents the content of the biologically active compounds in the non-fermented gingerbread grape (ie in the now sweeping sweet chacha) and fermented chacha.

Table 3.

BIOLOGICALLY ACTIVE COMPOUNDS IN ZEIMBER CHACHA

\begin{tabular}{lcccc}
\hline Zaimber Chacha & \multicolumn{4}{c}{ Biologically active compounds in mg / 100 dry mass } \\
\cline { 2 - 5 } & Phenolic compounds & Flavonoids & Flavon-3oids & Leuco-anthocyanins \\
\hline Non-fermented & 4765 & 941,7 & 1779,6 & 268,9 \\
Fermented & 2820 & 487,9 & 926,4 & 153,3 \\
\hline
\end{tabular}

The strong antioxidant polyphonic nutrient concentrate processed from the ecologically clean raw materials of Zimber's colored grapes produced by our richly rich composition and strong antioxidant activity of grape skin and biologically active compounds of grapes seeds and therefore has great medicinal prevention potential (Table 4).

Table 4.

CHEMICAL COMPOSITION OF STRONG ANTIOXIDANT, POLYPHONOLOGICAL FOOD ECO-CONCENTRATE AND ANTIOXIDANT ACTIVITY

\begin{tabular}{ccccc}
\hline Name & $\begin{array}{c}\text { Phenolic } \\
\text { compounds, } g / \mathrm{dm}^{3}\end{array}$ & Flavonoids, $\mathrm{g} / \mathrm{dm}^{3}$ & $\begin{array}{c}\text { Anthocyanins, } \\
\mathrm{g} / \mathrm{dm}^{3}\end{array}$ & $\begin{array}{c}\text { Antioxidant. } \\
\text { Activity, In-\%(F-5) }\end{array}$ \\
\hline Concentrate & 26,18 & 7,21 & 2,33 & 61,43 \\
\hline
\end{tabular}

The pharmacologic examination of this concentrate, obtained from the color of the varieties of ecologically pure grape varieties has been confirmed the drug-preventive efficiency of concentrate in the laboratory of the physiology department on the white rats of the Whistler breed.

Since the process of grape processing is seasonal, we have developed the latest technologies for preserving grape skin, which reduces the dried skin of up to $9 \%$ of the grapes from the microwave to $50-70 \mathrm{mms}$ and after the hydrothermal treatment of powders obtained granulation with DG-1 type granulator where matrices The diameter was $6-8 \mathrm{~mm}$. The granulation process is the best respiration of hydrophobic grapes. This process ensures the liquidation of active functional groups active in grapes. 
Composition of soluble substances in water and secondary bacterial researches obtained from various grape varieties, $70-73 \%$ in moisture conditions, at initial stage of settlement and after 3month storage in granules is given in Figure 3 [1].

The secondary resources of grape processing are the best raw materials: the curing-preventive powder, extracts, syrups, concentrates, pills, granules, alcohol, wine acid, grape seed oil, grape seed flour, nutriment paints, pectin, food fiber, tannin, granulated feed-stuff, the animal nutrition silage, fertilizers, etc. for the production of many other precious products. Therefore, it is very urgent and still has thousands of tons of secondary resources. It is necessary to process optimal technologies for their processing $[8,9]$.

Microbiological examination of the grape skin and the granules received from it was done by the method adopted, which provides for seeding and scratching on the food area.

Table 5

\section{BACTERIA AND FUNGUS CONTENT IN SAMPLES}

\begin{tabular}{lcc}
\hline \multicolumn{1}{c}{ Composition of research samples } & Before granulation & After granulation \\
\hline Microorganisms $1 \mathrm{~g}$. Sample bacteria, a thousand & $400 / 2400$ & $250 / 1200$ \\
Fungus, thousand & $3,0 / 11,8$ & $2,8 / 4,8$ \\
\hline
\end{tabular}

Note: The numerator displays the data before saving, and in the denomination after 3-month storage

In Figure 3, the A-shows the content of soluble substances in the initial stable and without B3-C - shows the content of soluble substances in the initial stage and after the D-3-months storage in the irreversible condition;

As for the phenolic compounds in the grapes skin, it was up to $7-8 \mathrm{~g} / \mathrm{kg}$, and after 3-month storage $6,3-7,2 \mathrm{~g} / \mathrm{kg}$. After granulation, the granules were initially contained in the same amount (7$8 \mathrm{~g} / \mathrm{kg}$ ) phenolic compounds, and after 3-month storage, $6,9-7,7 \mathrm{~g} / \mathrm{kg}$.

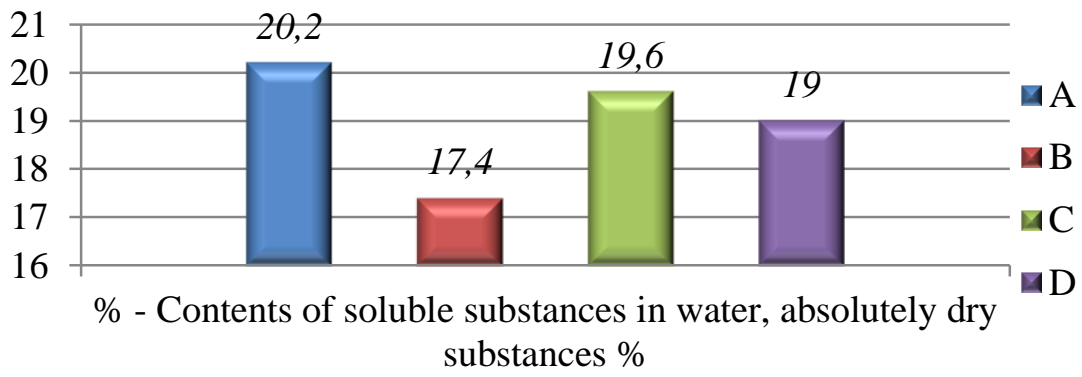

Figure 3. The results of the physical-chemical research of secondary resources obtained from different grape breeds

The analysis showed that the content of phenolic compounds is not changed after 3-month storage in the secondary granulated resources, which indicates the advantage of the preservation method. Besides, the procreation of bacteria and fungus is relatively active in the non-granulated grapes skin, rather than in the granulated ones (Table 5).

M. Alikhanov [10] has proposed to provide secondary gourmet recipe technology in the special pits where the calurea and sodium pyrosulphite are added to secondary raw materials as preservatives. In addition, the duration of the preservation process is 60 days and the biological active compounds of grape secondary resources are significantly variable.

The conceptual and economically substantiated clustered approach to the processing of secondary resources of the grape is developed by Ukrainian and Moldavian scientists. But there are no thousands of tons of secondary resources available, so no prescription methods are available that allow us to maintain the best possible biological active compounds (www.clustermdua). 


\section{Conclusion}

1. The bunch is washed with $86-93^{\circ} \mathrm{C}$ temperature water (for alcoholic spirits, for wine) and for the inactivation of biologically active compounds and mineral fertilizers for the inactivation of the sugar and the enzymes.

2. Bunch-free and diluted balderdash is washed with $86-93^{\circ} \mathrm{C}$ temperature water (for raw alcohol, for wine acid) and is supplied for drying till 9-10\% moisture content.

3.The dry balderdash is separated (divided) into the parts of skin and seed, the skin is delivered for the granulation (Shredding - hydrothermal processing - granulation, chills). The seeds and granulated grape skin is delivered for the storage in the storeroom of $70-72 \%$ relative humidity.

4. Obtained granulated skin and seeds are kept for a long time and create the best raw materials for making the curing-preventive powder, extracts, syrups, concentrates, pills, granules, alcohol, wine acid, grape seed oil, grape seed flour, nutriment paints, pectin, food fiber, tannin, granulated feed-stuff, the animal nutrition silage, fertilizers, etc. for the production of many other precious products.

\section{References:}

1. Gvinianidze T. N., Gvinianidze T. T., Chikovani P. M., Mindeli V. A., Djabnidze R. H. 2017Colored Grapes Byproducts as the Source for Bio-active Products. Scientific Journal "Juvenis Scientia, (8). 8-10.

2. Gvinianidze, T. N., Chikovani, P. M., Gvinianidze, T. T., Jabnidze, R. H., \& Mindeli, V. A. (2017). Colored grape polyphenol concentrate. Annals of Agrarian Science, 15(4), 472-475. https://doi.org/10.1016/j.aasci.2017.08.004

3. Gvinianidze, T. (2017). The grape skins and seed polyphenolic extracts. Bulletin of Science and Practice, 9 (22). 81-91.

4. Timush, A. I. (1986). Entsiklopediya vinogradarstva. Kishinev: Glavnaya redaktsiya Moldavskoi Sovetskoi Entsiklopedii. 502. (in Russian)

5. Gvinianize, T., Kalandia, A., \& Gvinianidze, T. (2016). Composition of Hydrophilic Extracts from Therapeutic Plants. Bulletin of Ak. Tsereteli State University, 2(6). 93-98.

6. Kishkovsky E. N., Skurikhin I. M. Chemistry of Wine, food Industry, Food industry, Moscow. 1976. (in Russian).

7. Gabidzashvili M. Developing Technologies and Quality Control Methods of Georgian Grape Seed Bioflavonoid Liquid Extracts. The thesis presented to obtain quality Doctor's degree. Kutaisi .2017.

8. Elegami, A. A., Bates, C., Gray, A. I., Mackay, S. P., Skellern, G. G., \& Waigh, R. D. (2003). Two very unusual macrocyclic flavonoids from the water lily Nymphaea lotus. Phytochemistry, 63(6), 727-731. https://doi.org/10.1016/S0031-9422(03)00238-3

9. Gvinianidze, T. (2018). Characteristic of the bone and skin of colored eco-grape varieties. Bulletin of Science and Practice, 4(11), 190-194. (in Russian)

10. Alikhanov M. Efficiency of using silage from grape waste in feeding sheep. Abstract of thesis for the degree of Candidate of Agricultural Sciences. Stavropol. 1997. 24. (in Russian)

\section{Список литературы:}

1. Гвинианидзе Т. Н., Гвинианидзе Т. Т., Чиковани П. М., Миндели В. А., Джабнидзе Р. Г. Вторичное сырье красного винограда как источник биологически активных соединений // Juvenis Scientia. 2017. №8. C. 8-10. 
2. Gvinianidze T. N. et al. Colored grape polyphenol concentrate //Annals of Agrarian Science. 2017. V. 15. №4. P. 472-475. https://doi.org/10.1016/j.aasci.2017.08.004

3. Gvinianidze T. The grape skins and seed polyphenolic extracts // Бюллетень науки и практики. 2017. №9. С. 81-91.

4. Тимуш А. И. Энциклопедия виноградарства. Кишинев: Главная редакция Молдавской Советской Энциклопедии. 1986. 502 с.

5. Гвинианидзе Т., Каландия А., Гвинианидзе Т. Композиция гидрофильных экстрактов из лечебных растений // Бюллетень государственного университета им. Ак. Церетели. 2016. №2(6). С. 93-98.

6. Кишковский 3. Н., Скурихин И. М. Химия вина. М.: Пищевая промышленность. 1976. $311 \mathrm{c}$.

7. Габидзашвили М. Разработка технологий и методов контроля качества биофлавоноидных жидких экстрактов семян винограда Грузии: дисс. ... д-ра наук. Кутаиси .2017.

8. Elegami A. A., Bates C., Gray A. I., Mackay S. P., Skellern G. G., Waigh R. D.Two very unusual macrocyclic flavonoids from the water lily Nymphaea lotus // Phytochemistry. 2003. V. 63. №6. P. 727-731. https://doi.org/10.1016/S0031-9422(03)00238-3

9. Гвинианидзе Т. Н. Характеристика косточек и кожицы цветных эко-сортов винограда // Бюллетень науки и практики. 2018. Т. 4. №11. С. 190-194.

10. Алиханов М. Эффективность использования силоса из виноградных отходов в кормлении овец: автореф. дисс. ... канд. с.-х. наук. Ставрополь. 1997. 24 с.

Работа поступила

в редакцию 23.05.2019 2.
Принята к публикаџии 28.05.2019 2.

\section{Ссылка для цчитирования:}

Gvinianidze T., Kamkamidze N., Tsutskiridze N. Some Aspects of Recycling and Storage of Secondary Resources of Grape // Бюллетень науки и практики. 2019. Т. 5. №7. С. 128-134. https://doi.org/10.33619/2414-2948/44/16

Cite as (APA):

Gvinianidze, T., Kamkamidze, N., \& Tsutskiridze, N. (2019). Some Aspects of Recycling and Storage of Secondary Resources of Grape. Bulletin of Science and Practice, 5(7), 128-134. https://doi.org/10.33619/2414-2948/44/16 